\title{
Donor organ cultured corneal tissue selection before penetrating keratoplasty
}

\author{
Vincent M Borderie, Sarah Scheer, Olivier Touzeau, Frédéric Vedie, \\ Santos Carvajal-Gonzalez, Laurent Laroche
}

\begin{abstract}
Aims-Donor organ cultured corneal tissue selection before penetrating keratoplasty is carried out by taking into account different variables. The objective was to identify preoperative variables which are significantly and independently associated with transplant outcome and should effectively be taken into account before transplantation.

Methods-231 consecutive penetrating keratoplasties were prospectively studied using organ cultured tissue. Morphometric analysis of the donor corneal endothelium was performed before transplantation. Graft survival and endothelial cell density, during the second year following transplantation, were studied both at a univariate and multivariate level.

Results-Recipient age, recipient rejection status, and preoperative diagnosis significantly influenced graft survival. Graft survival was higher when using corneal tissue from donors older than 80 years. Postoperative endothelial density decreased with preservation time and coefficient of variation after preservation. It increased with endothelial cell density after preservation and deswelling time, and correlated with preoperative diagnosis.

Conclusion-Organ cultured corneas with endothelial cell density after preservation $<2000$ cells $/ \mathrm{mm}^{2}$, and high coefficient of variation, may be discarded before transplantation. Corneas should be preserved for less than 3 weeks, and allowed to deswell before transplantation for 2 or 3 days rather than 1 day.
\end{abstract}

Banque de cornées Saint Antoine, ETS de l'APHP, Hôpital Saint Antoine, Paris, France V M Borderie

S Scheer

O Touzeau

F Vedie

L Laroche

INSERM Unité 339, Hôpital Saint Antoine, Paris, France

S Carvajal-Gonzalez

Correspondence to: Vincent M Borderie, MD, Service d'Ophtalmologie, Hôpital Saint Antoine, 184 rue du Fg St-Antoine, 75571 Paris Cedex 12, France.

Accepted for publication 5 November 1997

Organ culture is currently the most common corneal storage method used in Europe. Donor tissue selection before penetrating keratoplasty is carried out by taking into account different variables, such as corneal clarity at slit lamp examination, endothelial cell density and vitality, endothelial cell morphology, time to preservation, preservation time, and donor age. The Eye Bank Association of America (EBAA) and European Eye Bank Association (EEBA) have proposed criteria for accepting or discarding corneas. It is of interest to correlate these criteria with transplant outcome (that is, graft survival, graft endothelial cell density, and postoperative endothelial cell loss). Endothelial cell count seems to be a key variable ${ }^{1}$ when considering the postoperative endothelial cell loss. However, inaccuracy in cell density calculation is high (within 10\% of the actual cell density) when using specular ${ }^{2}$ or light microscopy. A dramatic improvement is obtained when using an image analysis system. A 1\% reliability of calculations of the endothelial cell density and coefficient of variation is then assessed with cell counts larger than 100 cells. $^{3}$ The exact relation between donor age and transplant outcome is still unclear. Studies generally demonstrated no decrease in graft survival with older donors. ${ }^{45}$

The aim of the present study was to assess the relation between preoperative variables and postoperative graft survival and endothelial cell count. A multivariate analysis including both donor, recipient, and surgical variables was performed in order to identify preoperative factors which are significantly and independently associated with transplant outcome and should be taken into account before transplantation.

\section{Materials and methods}

STUDY DESIGN

We prospectively studied 241 consecutive penetrating keratoplasties carried out in 231 patients between December 1992 and December 1995. Ten out of 241 (4\%) patients received two grafts. As these were not independent observations, we analysed our data excluding second grafts.

\section{DONOR CORNEAS}

Corneas were organ cultured in Inosol medium (Opsia, Toulouse, France) at $31^{\circ} \mathrm{C}$ for 14-35 days (mean 22.3 days, SD 5.7 days) as previously described. ${ }^{67}$ After enucleation and after organ culture, the central endothelium was evaluated by induced dilatation of intercellular spaces and trypan blue $(0.3 \%)$ staining, and was observed under a light microscope
(Olympus BHS). Photographs of the central endothelium were taken. In 34 corneas the endothelial cell density after enucleation could not be calculated owing to insufficient dilatation of intercellular spaces. Corneas were discarded for surgical use when they exhibited one or more of the following characteristics on light microscopic examination: an endothelial density less than 1500 cells $/ \mathrm{mm}^{2}$, uncontinuous cellular mosaic, percentage of dead cells greater than $2 \%$ after organ culture, severe polymegethism or pleomorphism of the endothelial cell pattern. Corneas with contaminated storage media were discarded before transplantation. Donor age was not considered as a reason to discard corneas. Younger donors 
Table 1 Patient characteristics ( $n=231$, second grafts excluded)

\begin{tabular}{|c|c|c|c|}
\hline \multicolumn{4}{|l|}{ Preoperative diagnosis: } \\
\hline Fuchs' dystrophy and ICE syndrome & 10 & \multicolumn{2}{|l|}{$(4.3 \%)$} \\
\hline Keratoconus & 66 & \multicolumn{2}{|l|}{$(28.6 \%)$} \\
\hline Bullous keratopathy & 106 & \multicolumn{2}{|l|}{$(45.9 \%)$} \\
\hline Other corneal dystrophies & 9 & \multicolumn{2}{|l|}{$(3.9 \%)$} \\
\hline Corneal scar, corneal ulcer, interstitial keratitis & 20 & \multicolumn{2}{|l|}{$(8.7 \%)$} \\
\hline Trauma & 8 & \multicolumn{2}{|l|}{$(3.4 \%)$} \\
\hline Regraft & 12 & \multicolumn{2}{|l|}{$(5.2 \%)$} \\
\hline \multicolumn{4}{|l|}{ Preoperative lens status: } \\
\hline Phakic & 115 & \multicolumn{2}{|l|}{$(49.8 \%)$} \\
\hline Posterior chamber IOL & 21 & \multicolumn{2}{|l|}{$(9.1 \%)$} \\
\hline Anterior chamber IOL & 71 & \multicolumn{2}{|l|}{$(30.7 \%)$} \\
\hline Aphakic & 24 & \multicolumn{2}{|l|}{$(10.4 \%)$} \\
\hline \multicolumn{4}{|l|}{ Preoperative intraocular pressure: } \\
\hline$<20 \mathrm{~mm} \mathrm{Hg}$ and no history of glaucoma & 192 & \multicolumn{2}{|l|}{$(83.1 \%)$} \\
\hline$>20 \mathrm{~mm} \mathrm{Hg}$ and/or history of glaucoma & 39 & \multicolumn{2}{|l|}{$(16.9 \%)$} \\
\hline \multicolumn{4}{|l|}{ Recipient rejection status: } \\
\hline Low risk & 181 & \multicolumn{2}{|l|}{$(78.3 \%)$} \\
\hline High risk & 50 & \multicolumn{2}{|l|}{$(21.7 \%)$} \\
\hline \multicolumn{4}{|c|}{ Table 2 Characteristics of corneas $(n=231$, second grafts excluded) } \\
\hline & Mean (SD) & Minimum & Maximum \\
\hline Endothelial density after enucleation (cells $/ \mathrm{mm}^{2}$ ) & $2867(520)$ & 1680 & 4560 \\
\hline Percentage cell death after enucleation (\%) & $1.09(2.07)$ & 0.00 & 10.00 \\
\hline Preservation time (days) & $22.3(5.7)$ & 14 & 35 \\
\hline Endothelial density after organ culture $\left(\right.$ cells $\left./ \mathrm{mm}^{2}\right)$ & $2336(381)$ & 1557 & 3546 \\
\hline Percentage cell death after organ culture (\%) & $0.23(0.49)$ & 0.00 & 2.00 \\
\hline $\begin{array}{l}\text { Coefficient of variation of endothelial cell area after } \\
\text { organ culture }(\%)\end{array}$ & $26.6(3.9)$ & 18.0 & 39.4 \\
\hline Percentage endothelial cell loss during organ culture (\%) & $16.2(14.1)$ & -5.1 & 44.2 \\
\hline
\end{tabular}

were not more likely to be used in younger recipients. After organ culture, corneas were incubated at room temperature with dextran containing Exosol medium (Opsia) for 1-3 days.

MORPHOMETRIC ANALYSIS OF THE ENDOTHELIUM Endothelial morphometric analysis was assessed with photographs of the central endothelium after organ culture using a Biocom Image Analysis System (Biocom, Les Ulis, France). One picture of each cornea showing at least 100 cells with clear contours was analysed. Photographs were illuminated from below by a fluorescent light table and the imaging was done with a video camera interfaced to a frame buffer board operating in a Pentium computer. For each digitised image, Visiolab 1000 software (Biocom) was used to analyse cells whose individual contours were obtained manually. The number of endothelial cells studied in each cornea ranged from 100 to 143. The average cell area (A), the coefficient

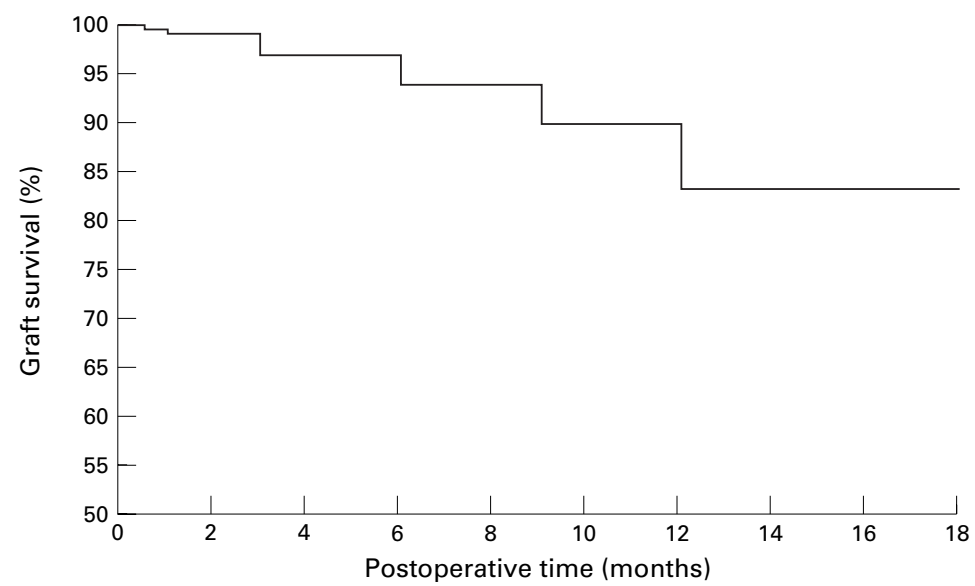

Figure 1 Overall graft survival (Kaplan-Meier method) of 231 consecutive penetrating keratoplasties. of variation (COV) of cell area (SD of the areas of the cells divided by A), and the endothelial density (D: 1/A) were calculated for each cornea. The first 45 corneas issued for transplantation were analysed by two different observers. The average percentage difference in endothelial cell density (that is, ( $\mid$ dens 1 dens $2|/|$ dens $1+$ dens $2 \mid / 2) \times 100$ ) between the two observers was $3.00 \%$ (SD $3.72 \%$ ).

SURGICAL AND MEDICAL TREATMENT

All transplants were performed at a single institution by seven surgeons. Two surgeons (LL, VMB) carried out $92.5 \%$ of the transplants. All donor buttons were punched from the posterior corneal surface by using the Hanna device. The average donor trephination size was $8.20 \mathrm{~mm}$ (SD 0.21 , range $7.25-8.50$ $\mathrm{mm}$ ), the donor size being $8.25 \mathrm{~mm}$ in $89.6 \%$ of the cases. The average recipient trephination size was $7.95 \mathrm{~mm}(0.21,7.00-8.25 \mathrm{~mm})$, the recipient size being $8.00 \mathrm{~mm}$ in $91.7 \%$ of the cases. All patients were given dexamethasone ointment at the end of surgery and were treated with topical dexamethasone $(1 \mathrm{mg} / \mathrm{ml})$ and neomycin $(3400 \mathrm{IU} / \mathrm{ml})$ afterwards. This treatment was tapered over a period of several months, from four times daily postoperatively to once daily at 6 months, without standardisation of postoperative steroid management. Most patients remained on a dosage of one drop every 2 days from 9 months after surgery until the time of suture removal. Sutures were removed routinely between 12 and 18 months.

Patients who developed signs of transplant rejection were treated with a variable dosage and route of steroids ranging from topical dexamethasone every waking hour during the first 7 days to a subconjunctival dexamethasone ( 2 $\mathrm{mg}$ ) injection once a day or systemic methylprednisolone $(500 \mathrm{mg}$ intravenously once a day for 3 days) followed by prednisone $(1 \mathrm{mg} / \mathrm{kg}$ orally).

RECIPIENTS AND TRANSPLANT OUTCOME

The patient mean age was 55.1 years (SD 22.9, range 9-92 years). Patient characteristics are shown in Table 1. High risk recipients were defined as having a vascularised cornea (two or more quadrants of corneal vascularisation) or a history of irreversible corneal allograft rejection.

Patients were hospitalised up to graft reepithelialisation. They were then examined at 2 weeks, 1, 3, 6, 9, 12, 18, 24, 30, and 36 months after surgery. Patients who lived outside France were examined by the ophthalmologist who referred them to us. The average follow up time was 18.3 (SD 9.2) months. At 1 year postoperatively, 219 eyes $(94.8 \%)$ were available for follow up, $11(4.8 \%)$ were lost for follow up, and one patient $(0.4 \%)$ died. The criteria for graft failure were irreversible graft stromal oedema or corneal opacification. We defined rejection as graft failure with rejection line, graft infiltrates, keratic precipitates, graft vascularisation, ciliary injection, or aqueous cells. The diagnosis of rejection was made only 
Table 3 Estimated 1 year graft survival. Donor variables

\begin{tabular}{|c|c|c|c|c|}
\hline Donor variable & No & $\begin{array}{l}\text { Univariate level } \\
\text { (Kaplan-Meier method) } \\
\text { Unadjusted estimated } 1 \\
\text { year graft survival }\end{array}$ & $p$ Value & $\begin{array}{l}\text { Multivariate level } \\
\text { (Cox model) } p \\
\text { value }\end{array}$ \\
\hline \multicolumn{5}{|c|}{ Donor age (years): } \\
\hline$<50$ & 13 & $82.5 \%$ & $0.90(\mathrm{NS})^{\star}$ & \\
\hline$>50$ & 218 & $84.3 \%$ & & \\
\hline$<60$ & 61 & $87.6 \%$ & $0.53(\mathrm{NS})^{\star}$ & \\
\hline$>60$ & 170 & $83.0 \%$ & & \\
\hline$<70$ & 102 & $86.3 \%$ & $0.98(\mathrm{NS})^{\star}$ & \\
\hline$>70$ & 129 & $82.6 \%$ & & \\
\hline$<80$ & 171 & $81.7 \%$ & & \\
\hline$>80$ & 60 & $91.3 \%$ & $0.024^{\star}$ & 0.005 \\
\hline$<90$ & 223 & $84.1 \%$ & & \\
\hline$>90$ & 8 & $87.5 \%$ & $0.63(\mathrm{NS})^{\star}$ & \\
\hline$<50$ & 13 & $82.5 \%$ & & \\
\hline $51-60$ & 48 & $88.9 \%$ & & \\
\hline $61-70$ & 41 & $84.4 \%$ & & \\
\hline $71-80$ & 69 & $75.4 \%$ & & \\
\hline $81-90$ & 52 & $91.9 \%$ & & \\
\hline$>90$ & 8 & $87.5 \%$ & $0.55(\mathrm{NS})^{\star}$ & \\
\hline \multicolumn{5}{|c|}{ Preservation time (days): } \\
\hline$<21>21$ & 13794 & $89.2 \% 77.1 \%$ & $0.012^{\star}$ & 0.30 (NS) \\
\hline \multicolumn{5}{|c|}{ Endothelial density after preservation $\left(\right.$ cells $\left./ \mathrm{mm}^{2}\right)$ : } \\
\hline$<1800$ & 14 & $69.2 \%$ & & \\
\hline$>1800$ & 217 & $85.1 \%$ & $0.28(\mathrm{NS})^{\star}$ & \\
\hline$<2000$ & 52 & $76.1 \%$ & & \\
\hline$>2000$ & 179 & $86.6 \%$ & $0.050^{\star}$ & 0.22 (NS) \\
\hline$<2500$ & 158 & $83.0 \%$ & & \\
\hline$>2500$ & 73 & $86.8 \%$ & $0.67(\mathrm{NS})^{\star}$ & \\
\hline$<3000$ & 220 & $83.9 \%$ & & \\
\hline$>3000$ & 11 & $90.0 \%$ & $0.79(\mathrm{NS})^{\star}$ & \\
\hline$<2000$ & 48 & $76.2 \%$ & & \\
\hline $2000-2499$ & 108 & $85.6 \%$ & & \\
\hline$>2500$ & 75 & $87.2 \%$ & $0.21(\mathrm{NS})^{\star}$ & \\
\hline
\end{tabular}

${ }^{\star} \log$ rank test for trend.

Table 4 Estimated 1 year graft survival. Recipient and surgical variables

\begin{tabular}{|c|c|c|c|c|}
\hline Recipient and surgical variable: & No & $\begin{array}{l}\text { Univariate level } \\
\text { (Kaplan-Meier } \\
\text { method) }\end{array}$ & $p$ Value & $\begin{array}{l}\text { Multivariate } \\
\text { level }\end{array}$ \\
\hline \multicolumn{5}{|l|}{ Recipient age (years): } \\
\hline$<20$ & 20 & $88.9 \%$ & & \\
\hline $21-30$ & 31 & $100.0 \%$ & & \\
\hline $31-40$ & 20 & $85.0 \%$ & & \\
\hline $41-50$ & 23 & $77.3 \%$ & & \\
\hline $51-60$ & 15 & $93.3 \%$ & & \\
\hline $61-70$ & 40 & $75.8 \%$ & & \\
\hline $71-80$ & 53 & $81.7 \%$ & & \\
\hline$>81$ & 29 & $78.9 \%$ & $0.010^{\star}$ & 0.05 \\
\hline \multicolumn{5}{|l|}{ Recipient rejection status: } \\
\hline low risk & 181 & $90.2 \%$ & & \\
\hline high risk & 50 & $60.9 \%$ & $<0.0001$ & 0.01 \\
\hline \multicolumn{5}{|l|}{ Preoperative diagnosis: } \\
\hline Fuchs' dystrophy and ICE syndrome & 10 & $100.0 \%$ & & \\
\hline Keratoconus & 66 & $98.5 \%$ & & \\
\hline Other dystrophies & 9 & $87.5 \%$ & & \\
\hline Bullous keratopathy & 106 & $80.5 \%$ & & \\
\hline Trauma & 8 & $75.0 \%$ & & \\
\hline Corneal scar/ulcer, interstitial keratitis & 20 & $63.2 \%$ & & \\
\hline Regraft & 12 & $58.3 \%$ & $<0.0001$ & 0.005 \\
\hline \multicolumn{5}{|l|}{ Recipient trephination size $(\mathrm{mm})$ : } \\
\hline $7.00-7.75$ & 18 & $64.7 \%$ & & \\
\hline $8.00-8.25$ & 213 & $85.8 \%$ & 0.002 & 0.10 (NS) \\
\hline \multicolumn{5}{|l|}{ Preop IOP: } \\
\hline No glaucoma and IOP $<20 \mathrm{~mm} \mathrm{Hg}$ & 192 & $85.8 \%$ & & \\
\hline Glaucoma or IOP $>20 \mathrm{~mm} \mathrm{Hg}$ & 39 & $76.3 \%$ & 0.050 & 0.38 (NS) \\
\hline \multicolumn{5}{|l|}{ Postop lens status: } \\
\hline Aphake & 12 & $82.5 \%$ & & \\
\hline Ant chamber IOL & 84 & $79.2 \%$ & & \\
\hline Post chamber IOL & 46 & $75.0 \%$ & & \\
\hline Phake & 89 & $93.2 \%$ & 0.003 & 0.84 (NS) \\
\hline \multicolumn{5}{|l|}{ Combined procedures: } \\
\hline Vitrectomy & 46 & $75.8 \%$ & & \\
\hline No vitrectomy & 185 & $86.1 \%$ & 0.008 & 0.19 (NS) \\
\hline Lens removal & 26 & $64.0 \%$ & & \\
\hline No lens removal & 205 & $86.7 \%$ & 0.005 & 0.11 (NS) \\
\hline PC IOL insertion & 28 & $64.3 \%$ & & \\
\hline No PC IOL insertion & 203 & $87.1 \%$ & 0.006 & 0.63 (NS) \\
\hline
\end{tabular}

$\star \log$ rank test for trend. in the country. The postoperative percentage endothelial cell loss was calculated as follows:

(endothelial cell density after preservation postop endothelial cell density)/endothelial cell density after preservation $\times 100$.

STATISTICAL ANALYSIS

We studied unadjusted graft survival with the Kaplan-Meier method and compared the data with the log rank test. We then performed a multivariate Cox proportional hazards analysis, including variables that were significant at a univariate level $(p<0.05)$. Relative risk with the $95 \%$ confidence interval, obtained with Cox analysis, is given for variables that are significant at a multivariate level $(\mathrm{p}<0.05)$. We studied postoperative endothelial cell density and postoperative percentage endothelial cell loss using the Spearman's rank correlation coefficient. Multiple linear regression was then performed with variables that were significant at a univariate level. We studied both donor variables (that is, donor age, endothelial cell density, and vitality after enucleation and after preservation, COV after preservation, percentage endothelial cell loss during preservation, death to enucleation time, death to preservation time, preservation time, deswelling time), and recipient and surgical variables (that is, recipient age, preoperative diagnosis, recipient rejection status (high risk or low risk), donor trephination size, recipient trephination size, preoperative intraocular pressure, preoperative lens status, postoperative lens status, and combined procedures). As we aimed to assess criteria for accepting or discarding donor corneas before transplantation, donor variables were studied using different thresholds in order to find which threshold best set apart suitable and unsuitable corneas. Considering the high correlation among respectively donor and recipient trephination size, and preoperative and postoperative lens status, we only included recipient trephination size and postoperative lens status in the multivariate models.

\section{Results}

DONOR CORNEAS

Corneas were characterised by an average donor age of 70.8 years (SD 12.5, range 42-95 years) with an average postmortem time (death to enucleation) of 20.2 hours (10.8, 5-48 hours), and an average death to preservation time of 24.0 hours (10.9, 7-54 hours). The percentage of transplanted corneas was $68 \%$ (241 out of 356). The cornea characteristics are outlined in Table 2.

The donor endothelial cell density after preservation decreased with donor age $\left(\mathrm{r}_{\mathrm{s}}=\right.$ $-0.14, p=0.03)$, death to enucleation time $\left(r_{s}\right.$ $=-0.25, \mathrm{p}<0.001)$, death to preservation time ( $\mathrm{rs}=-0.26, \mathrm{p}<0.001$ ), and percentage cell death after enucleation $\left(r_{s}=-0.15, p=0.02\right)$. After stratification for donor age, endothelial cell density after preservation still correlated with death to enucleation time $(r=-0.26, \mathrm{p}<$ $0.001)$ and death to preservation time ( $\mathrm{r}=$ $-0.26, \mathrm{p}<0.001$ ), whereas correlation with percentage cell death after enucleation was no longer significant $(r=-0.11, p=0.12)$. In if the transplant had remained clear for an interval of at least 2 weeks after surgery.

During the second year after transplantation contact wide field specular microscopy was performed in clear transplants of patients living 


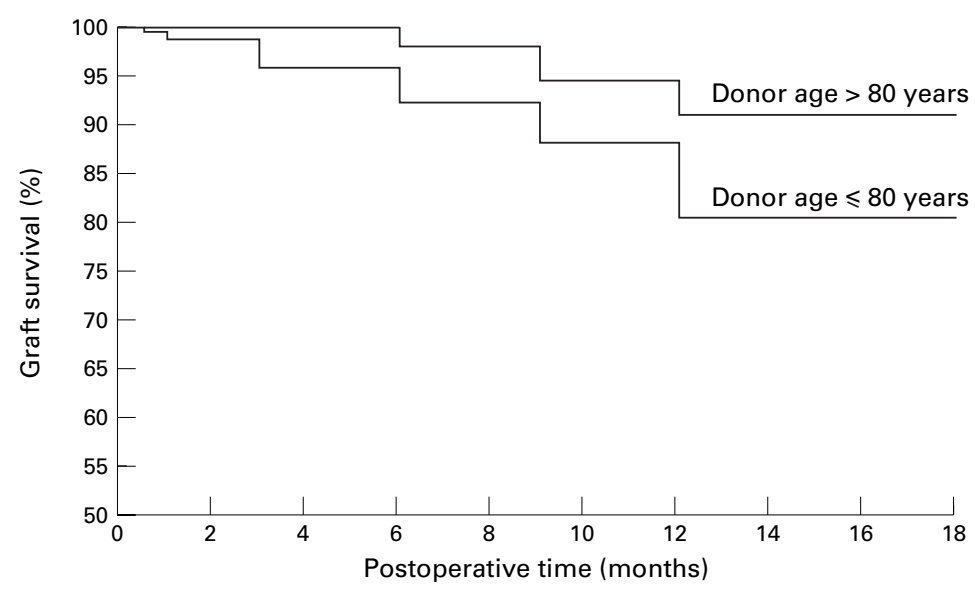

Figure 2 Influence of donor age on graft survival (Kaplan-Meier method). Log rank: $p$ $=0.024$. Multivariate Cox hazards model: $p=0.005$.

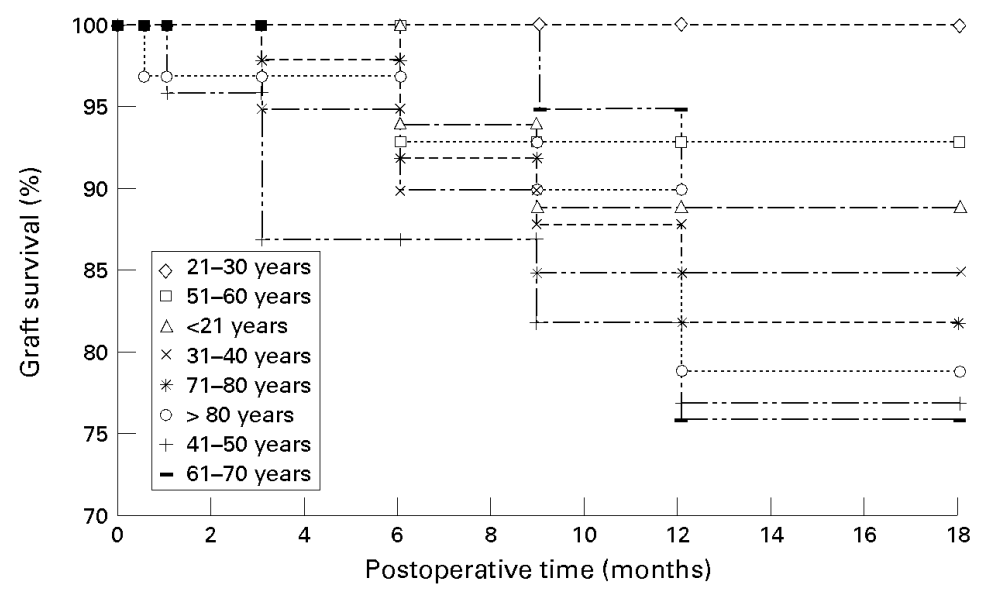

Figure 3 Influence of recipient age on graft survival (Kaplan-Meier method). Log rank: $p=0.049$. Multivariate Cox hazards model: $p=0.05$.

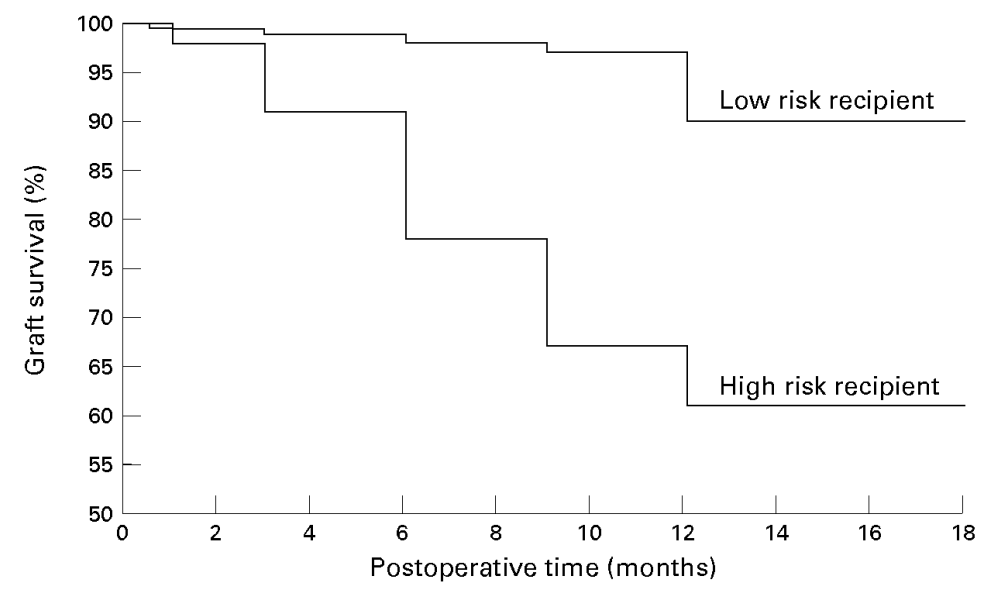

Figure 4 Influence of recipient rejection status on graft survival (Kaplan-Meier method). Log rank: $p<0.0001$. Multivariate Cox hazards model: $p=0.01$.

addition, percentage endothelial cell loss during preservation increased with endothelial cell density after enucleation $\left(r_{s}=0.59, p<0.001\right)$.

OVERALL OUTCOME

The 1 year graft survival estimate was $84.2 \%$ (Fig 1). Graft failure occurred in 45 out of the 231 eyes. Allograft rejection was the leading cause of failure as it occurred in 25 eyes $(55.6 \%)$. Glaucoma was responsible for failure in 10 eyes (22.2\%). Corneal endothelial decompensation without rejection was responsible for failure in eight eyes $(17.8 \%)$. Other causes of graft failure $(4.4 \%)$ included persistent epithelial defect (one eye) and expulsive haemorrhage (one eye). Except for the eye that failed as a result of expulsive haemorrhage, no primary graft failure occurred. During the second year (mean 14.8 months, SD 3.3) following transplantation, 128 clear transplants were studied by means of specular microscopy. The average endothelial cell density was 1508 cells/ $\mathrm{mm}^{2}$ (SD 608), corresponding to a $34.7 \%$ postoperative percentage endothelial cell loss (SD 25.4).

EFFECT OF DONOR, SURGICAL, AND RECIPIENT VARIABLES ON GRAFT SURVIVAL

Tables 3 and 4 shows the variables that were significant at a univariate level and that were used for the multivariate analysis. Among these, donor age (Fig 2), recipient age (Fig 3), recipient rejection status (Fig 4), and preoperative diagnosis (Fig 5) significantly influenced graft survival at a multivariate level. In the multivariate Cox model, the relative risk of failure was $4.3(1.5,11.8)$ for donor younger than 80 years compared with donors older than 80 years. It was $2.7(1.3,5.9)$ for high risk recipients compared with low risk recipients. Preservation time, endothelial cell density after preservation, recipient trephination size, preoperative intraocular pressure, postoperative lens status, associated vitrectomy, lens removal, and posterior chamber IOL insertion significantly influenced graft survival only at a univariate level. Death to enucleation time, death to preservation time, endothelial cell density after enucleation, percentage cell death before and after preservation, endothelial cell loss during preservation, COV after preservation, deswelling time, associated IOL removal, and anterior chamber IOL insertion had no significant influence on graft survival.

EFFECT OF DONOR, SURGICAL, AND RECIPIENT VARIABLES ON POSTOPERATIVE ENDOTHELIAL CELL DENSITY

Table 5 shows the variables that were significant at a univariate level and that were used for the multivariate analysis. Among these, five significantly correlated with postoperative endothelial cell density (PED) in multiple linear regression analysis. PED decreased with preservation time and COV after preservation. It increased with endothelial cell density after preservation, and deswelling time, and correlated with preoperative diagnosis. Recipient age, preoperative intraocular pressure, postoperative lens status, associated vitrectomy, IOL removal, anterior chamber IOL insertion, and trabeculectomy significantly correlated with PED only at a univariate level. Donor age, death to enucleation time, death to preservation time, endothelial cell density after enucleation, percentage cell death before and after preservation, endothelial cell loss during preservation, rejection status, recipient trephination size, associated lens removal and posterior 
Table 5 Relation between donor, surgical, and recipient variables, and endothelial cell density, and endothelial cell loss during the second year following transplantation

\begin{tabular}{|c|c|c|c|c|c|c|}
\hline & \multicolumn{3}{|c|}{$\begin{array}{l}\text { Correlation with postoperative endothelial cell } \\
\text { density }\end{array}$} & \multicolumn{3}{|c|}{$\begin{array}{l}\text { Correlation with postoperative percentage endothelial } \\
\text { cell loss }\end{array}$} \\
\hline & \multicolumn{2}{|c|}{$\begin{array}{l}\text { Spearman's coefficient } \\
\text { (univariate level) }\end{array}$} & \multirow{2}{*}{$\begin{array}{l}\text { Multiple linear } \\
\text { regression }\end{array}$} & \multicolumn{2}{|c|}{$\begin{array}{l}\text { Spearman's coefficient } \\
\text { (univariate level) }\end{array}$} & \multirow{2}{*}{$\begin{array}{l}\begin{array}{l}\text { Multiple linear } \\
\text { regression }\end{array} \\
P\end{array}$} \\
\hline & $r_{s}$ & $P$ & & $r_{s}$ & $P$ & \\
\hline \multicolumn{7}{|l|}{ Donor variable: } \\
\hline Preservation time & -0.30 & $<0.001$ & 0.014 & +0.31 & $<0.001$ & 0.011 \\
\hline $\begin{array}{l}\text { Endothelial density after } \\
\text { preservation }\end{array}$ & +0.30 & $<0.001$ & 0.002 & -0.05 & 0.59 (NS) & 0.030 \\
\hline COV after preservation & -0.28 & 0.004 & 0.017 & +0.27 & 0.005 & 0.018 \\
\hline $\begin{array}{l}\text { Deswelling time after } \\
\text { preservation }\end{array}$ & +0.20 & 0.022 & 0.008 & -0.19 & 0.031 & \\
\hline \multicolumn{7}{|c|}{ Recipient and surgical variable: } \\
\hline Recipient age & -0.30 & $<0.001$ & 0.49 (NS) & +0.25 & 0.003 & 0.60 (NS) \\
\hline Preop diagnosis & -0.30 & $<0.001$ & 0.012 & +0.30 & $<0.001$ & 0.009 \\
\hline Preoperative IOP & -0.29 & 0.001 & 0.96 (NS) & +0.27 & 0.002 & 0.82 (NS) \\
\hline Postop lens status & +0.41 & $<0.001$ & 0.12 (NS) & -0.39 & $<0.001$ & 0.16 (NS) \\
\hline \multicolumn{7}{|l|}{ Combined procedures: } \\
\hline Vitrectomy & -0.25 & 0.003 & 0.89 (NS) & +0.22 & 0.011 & 0.81 (NS) \\
\hline IOL removal & -0.31 & $<0.001$ & 0.15 (NS) & +0.28 & 0.001 & 0.26 (NS) \\
\hline AC IOL insertion & -0.28 & 0.001 & 0.54 (NS) & +0.28 & 0.001 & 0.85 (NS) \\
\hline Trabeculectomy & -0.27 & 0.001 & 0.57 (NS) & +0.27 & 0.001 & 0.41 (NS) \\
\hline
\end{tabular}

chamber IOL insertion, and postoperative time did not significantly correlate with PED.

EFFECT OF DONOR, SURGICAL, AND RECIPIENT VARIABLES ON POSTOPERATIVE PERCENTAGE ENDOTHELIAL CELL LOSS

Table 5 shows the variables that were significant at a univariate level and that were used for the multivariate analysis. Among these, four significantly correlated with postoperative percentage endothelial cell loss (PEL) in multiple linear regression analysis. PEL increased with preservation time and COV after preservation. It decreased with deswelling time, and correlated with preoperative diagnosis. Recipient age, preoperative intraocular pressure, postoperative lens status, associated vitrectomy, IOL removal, anterior chamber IOL insertion, and trabeculectomy significantly correlated with PEL only at a univariate level. Donor age, death to enucleation time, death to preservation time, endothelial cell density after enucleation, percentage cell death before and after preservation, endothelial cell density after preservation, endothelial cell loss during preservation, rejection status, recipient trephination size, associated lens removal and posterior

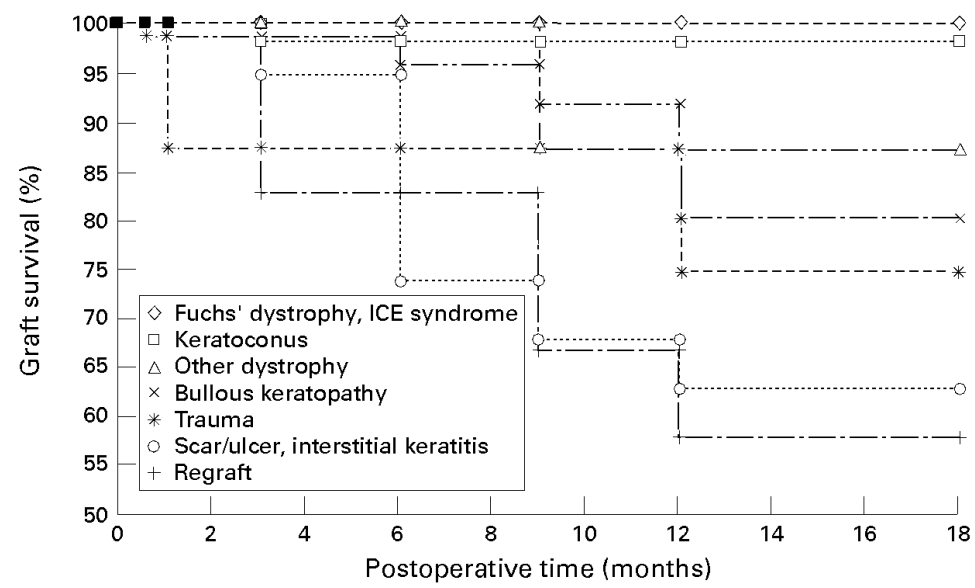

Figure 5 Influence of preoperative diagnosis on graft survival (Kaplan-Meier method). Log rank: $p<0.0001$. Multivariate Cox hazards model: $p=0.005$. chamber IOL insertion, and postoperative time did not significantly correlate with PEL.

\section{Discussion}

In a single centre prospective study of 231 consecutive penetrating keratoplasties, we found the 1 year graft survival estimate to be $84.2 \%$. Graft survival at 1 year is reported to range from $80 \%$ to $98 \%$ in the literature. ${ }^{4-10}$ Many studies are based on reports from corneal graft registries, and do not analyse consecutive keratoplasties. As a consequence, the present series includes a large number of fair prognosis transplants (not only recipients with a vascularised cornea, or a history of allograft rejection, but also glaucomatous patients). In fact, allograft rejection was the leading cause of graft failure, accounting for $56 \%$ of failures. This high rate of immunological failure is probably responsible for the relatively low 1 year graft survival estimate $(84.2 \%)$ compared to recent studies. ${ }^{511}$ It is noteworthy that $22 \%$ of our recipients were high risk recipients, and that the recipient rejection status strongly influenced graft survival. In fact, the high risk recipient 1 year graft survival estimate was $61 \%$, to be compared with $90 \%$ for low risk recipients. This influence of corneal vascularisation and history of allograft rejection on allograft rejection is in accordance with other studies. ${ }^{12-14}$ In addition patients with aphakic and pseudophakic eyes were not kept on topical corticosteroids indefinitely. Several episodes of allograft rejection occurred when this treatment was stopped. This may be responsible for our $80.5 \%$ bullous keratopathy 1 year graft survival, which is lower than that recently reported by others. ${ }^{515}$ However, Williams et al ${ }^{9}$ also demonstrated a higher graft survival for patients with keratoconus or other corneal dystrophies than patients with no dystrophy, which is in accordance with our findings.

Overall graft survival was used as a variable to test corneal tissue selection criteria. We must highlight that allograft rejection and glaucoma were responsible for $78 \%$ of the failures. Excluding patients who experienced 
rejection or glaucoma would lead to too small a number of cases for any analysis to be carried out. As recipient rejection status and preoperative intraocular pressure were included in the multivariate model, we can state that donor variables that were significant at a multivariate level influenced graft survival independent of the effect of recipient variables. Twenty three variables were studied at a univariate level. In order not to include too many variables in the multivariate model, only variables that showed a relatively high level of significance $(p<5 \%)$ in univariate analysis were used for the multivariate analysis.

Factors that significantly influenced graft survival in multivariate analysis were donor age, recipient rejection status, recipient age, and preoperative diagnosis. Surprisingly, graft survival was higher when using corneal tissue from donors older than 80 years. This statistical association between graft survival and old donors was strong as it was present both at a univariate and multivariate level. The explanation for this is unclear. Most studies have demonstrated no influence of donor age on graft survival. ${ }^{45911} 121617$ The age of donors in the present study (mean 71 years) is generally higher than that of other studies. Recently, Armitage and Easty ${ }^{18}$ analysed the suitability of 9250 organ cultured corneas for keratoplasty. They showed a slower decline in endothelial quality during organ culture with increasing donor age. They concluded that corneal endothelial cells of older donors are more stable during organ culture than are those of young donors. This would imply that old donor tissue would more likely survive transplantation induced stress, which is in accordance with increased graft survival. However, no significant effect of donor age on postoperative endothelial density was observed. Another explanation could be that old tissue would be less likely to promote graft rejection. This immunological mechanism would be in accordance with the absence of correlation between donor age and postoperative endothelial cell density within clear transplants (that is, transplants that did not experience allograft rejection). When it seems difficult to suggest routinely using old donor tissue rather than young donor tissue, old donor tissue should not be discarded for transplantation when endothelial quality control is performed before transplantation.

Specular microscopy was performed in 128 clear transplants during the second year following transplantation. As postoperative endothelial cell density and cell loss did not correlate with postoperative time, we did not adjust the analysis to postoperative time. Factors that significantly influenced postoperative endothelial cell density in multivariate analysis were preservation time, endothelial density after preservation, coefficient of variation after preservation, deswelling time, and preoperative diagnosis. Bourne et al ${ }^{19}$ found no significant correlation between the endothelial cell loss from 3 to 5 years after keratoplasty and either donor age or recipient age, or relation at 1 year between cell loss and donor cell density.
The use of a morphometric analysis system allows a high precision in cell density calculation to be obtained. The relation between preoperative and postoperative endothelial cell density is more likely to be found statistically significant. Donor corneas with more than 2000 cells $/ \mathrm{mm}^{2}$, and/or a low coefficient of variation after preservation were associated with significantly higher postoperative endothelial cell densities. Musch et $a l^{1}$ analysed retrospectively 265 grafts out of 1333 penetrating keratoplasties carried out during a 5 year period. Corneas obtained from older donors, corneas with higher endothelial cell density, and corneas transplanted to older recipients demonstrated a greater percentage of loss of endothelial cell density 1 year after surgery. In the present study, we found a similar relation between endothelial density after enucleation and percentage endothelial cell loss during preservation but not between preoperative endothelial density (either before or after preservation) and postoperative percentage cell loss. The use of organ culture for corneal storage in our study may be responsible for this difference. In addition, recipient age significantly influenced postoperative percentage cell loss only at a univariate level and not at a multivariate level.

Coefficient of variation of endothelial cell area is not routinely calculated before transplantation. This calculation implies the use of a morphometric analysis system at the eye bank. We showed that COV was a prognosis factor for postoperative endothelial cell density, and should be taken into account before transplantation. This influence was independent of preoperative endothelial cell density effect. The COV values obtained in the present study were lower than that previously described with human donor corneas. ${ }^{70}$ The exact threshold for accepting corneas for transplantation probably needs to be defined in local conditions (that is, the analysis system, light or specular microscope, technicians' practice) and in further studies on larger series of patients.

We found an average $16 \%$ percentage endothelial cell loss during organ culture, varying from $-5 \%$ to $44 \%$. This is consistent with findings published by Pels and Schuchard who found a relative cell loss during organ culture varying from $-10 \%$ to $30 \%$ for organ culture periods $<30$ days. ${ }^{21} \mathrm{~A}$ wide range of endothelial cell densities was observed as was found by others. ${ }^{22}$ We must point out that the SD of endothelial cell density was higher after enucleation (520 cells $\left./ \mathrm{mm}^{2}\right)$ than after organ culture (381 cells $\left./ \mathrm{mm}^{2}\right)$. This may be explained by better visualisation of cell contours obtained after organ culture compared with fresh tissue, which improves endothelial cell count precision. This effect is certainly due to organ culture induced dilatation of endothelial intercellular spaces. ${ }^{6}$ Lastly, the presence of a low percentage of dead cells (mean $0.23 \%$, SD 0.49 ) in the monolayer after organ culture is probably related to the increasing endothelial cell loss, significantly correlated with organ culture time - that is, observed during organ 
culture for storage periods varying from 0 to 3 months. ${ }^{21}$

In conclusion, we would propose discarding corneas with endothelial cell density after preservation of $<2000$ cells $/ \mathrm{mm}^{2}$, and high coefficient of variation. It seems to be better to preserve corneas for less than 3 weeks, and to allow them to deswell before transplantation for 2 or 3 days rather than 1 day, when using organ culture. Endothelial quality control after enucleation is of no interest as its results did not influence graft survival or postoperative endothelial cell density.

This work was supported by the Fondation Claude Bernard pour le développement des recherches biologiques et médicales dans les Hôpitaux de l'Assistance Publique à Paris.

1 Musch DC, Meyer RF, Sugar A. Predictive factors for endothelial cell loss after penetrating keratoplasty. Arch Ophthalmol 1993;111:80-3.

2 Hirst LW, Yamauchi K, Enger C, et al. Quantitative analysi of wide-field specular microscopy. Invest Ophthalmol Vis Sci 1989;30:1972-9.

3 Doughty MJ, Desmond F, Nguyen KT. Assessement of the reliability of calculations of the coefficient of variation for normal and polymegethous human corneal endothelium. Optom Vis Sci 1993;70:759-70.

4 Chang SD, Pecego JG, Zadnik K, et al. Factors influencing graft clarity. Cornea 1996;15:577-81.

5 Price FW, Whitson WE, Johns S, et al. Risk factors for corneal graft failure. F Refract Surg 1996;12:134-47.

6 Borderie VM, Kantelip BM, Delbosc BY, et al. Morphology, Borderie VM, Kantelip BM, Delbosc BY, et al. Morphology,
histology and ultrastructure of human C31 organ-cultured histology and ultrastructure of hum

7 Borderie VM, Baudrimont M, Lopez M, et al. Evaluation of the deswelling period in Dextran-containing medium after corneal organ culture. Cornea 1997;16:215-23.
8 Vail A, Gore SM, Bradley BA, et al. Clinical and surgical factors influencing corneal graft survival, visual acuity, and astigmatism. Ophthalmology 1996;103:41-9.

9 Williams KA, Roder DR, Esterman A, et al. Factors predictive of corneal graft survival. Report from the Australian Corneal Graft Registry. Ophthalmology 1992;99:403-14

10 Price FW, Whitson WE, Collins KS, et al. Five-year corneal graft survival. A large, single-center patient cohort. Arch Ophthalmol 1993;111:799-805.

11 Vail A, Gore SM, Bradley BA, et al. Influence of donor and histocompatibility factors on corneal graft outcome. Transplantation 1994;58:1210-7.

12 Boisjoly HM, Tourigny R, Bazin R, et al. Risk factors of corneal graft failure. Ophthalmology 1993;100:1728-35.

13 Boisjoly HM, Raynald R, Bernard PM, et al. Association between corneal allograft reactions and HLA compatibility. Ophthalmology 1990;97:1689-98.

14 Borderie VM, Lopez M, Vedie F, et al. ABO antigen blood group compatibility in corneal transplantation. Cornea 1997;16:1-6.

15 Kwartz J, Leatherbarrow B, Dyer P, et al. Penetrating keratoplasty for pseudophakic corneal oedema. $\mathrm{Br} \mathcal{F}$ Ophthalmol 1995;79:435-8.

16 Volker-Dieben HJ, Kok-Van Alphan CC, Landsbergen Q, et al. Different influences on corneal graft survival in 539 transplants. Acta Ophthalmol 1982;60:190-202.

17 Forster RK, Fine M. Relation of donor age to success in penetrating keratoplasty. Arch Ophthalmol 1971;85:42-7.

18 Armitage WJ, Easty DL. Factors influencing the suitability of organ-cultured corneas for transplantation. Invest of organ-cultured corneas for
Ophthalmol Vis Sci 1997;38:16-24.

19 Bourne WM, Hodge DO, Nelson LR. Corneal endothelium five years after transplantation. Am $\mathcal{F}$ Ophthalmol 1994;118: 185-96.

20 Matsuda M, Yee RW, Glasser DB, et al. Specular microscopic evaluation of donor corneal endothelium. Arch Ophthalmol 1986;104:259-62.

21 Pels E, Schuchard Y. Organ culture in the Netherlands. In: Brightbill FS, ed. Corneal surgery. Theory, technique and tissue. 2nd ed. St Louis: Mosby, 1993:622-32.

22 Schimmelpfennig BH. Tissue storage and tissue typing. Short term state of the art. In: Brightbill FS, ed. Corneal surgery. Theory, technique and tissue. 2nd ed. St Louis: Mosby, 1993:597-608. 